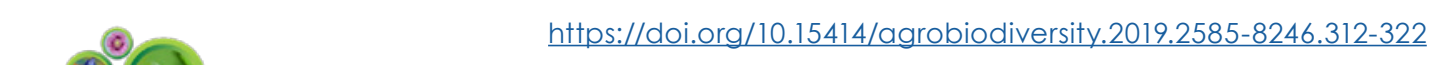

AGROBIODIVERSITY

FOR IMPROVING NUTRITION, HEALTH AND LIFE QUALITY 2019

$\Theta$

\title{
SCREENING FOR ANTIMICROBIAL ACTIVITY OF NINE ETHANOLIC EXTRACTS OBTAINED FROM LEAVES OF BEGONIA PLANT: A POSSIBLE ALTERNATIVE IN THE TREATMENT OF INFECTIONS CAUSED BY CITROBACTER FREUNDII
}

\author{
Buyun Lyudmyla ${ }^{1}$, Tkachenko Halyna* ${ }^{*}$, Kurhaluk Natalia ${ }^{2}$, \\ Góralczyk Anna ${ }^{2}$, Tomin Vładimir ${ }^{3}$, Osadowski Zbigniew ${ }^{2}$ \\ ${ }^{1}$ M.M. Gryshko National Botanic Garden, National Academy of Science of Ukraine, Kyiv, Ukraine \\ ${ }^{2}$ Institute of Biology and Earth Sciences, Pomeranian University in Słupsk, Poland \\ ${ }^{3}$ Department of Physics, Pomeranian University in Słupsk, Poland
}

Received: 15.11.2019 Revised: 27. 11.2019 Published: 30.11. 2019

\begin{abstract}
Many plants of the family Begoniaceae are used in the treatment of different diseases. Traditionally leaves of Begonia L. are used to decrease of fleeting pain in the limbs and joints, for blood purification, to reduce the body temperature, for treating anemia, for the treatment of respiratory infections, diarrhea, blood cancer, and skin diseases, peptic ulcer, conjunctivitis, colic and dyspepsia, dysentery and mouth ulcer. Moreover, the leaves of Begonia species are used for the treatment of cancer; besides, they possess anti-HIV activity. Some of the plants of the genus Begonia were previously reported for their antimicrobial activities. The antimicrobial activity of ethanolic extracts obtained from the leaves of Begonia solimutata L.B. Sm. \& Wassh., Begonia goegoensis N.E.Br., Begonia foliosa Kunth, Begonia $\times$ erythrophylla Hérincq, Begonia thiemei C.DC., Begonia peltata Otto \& Dietr., Begonia heracleifolia Cham. \& Schltdl., Begonia dregei Otto \& Dietr., and Begonia mexicana G. Karst. ex Fotsch was evaluated against the clinical strain of Citrobacter freundii strain. The testing of the antibacterial activity of the plant extracts was carried out in vitro by the Kirby-Bauer disc diffusion technique. All ethanolic extracts obtained from leaves of Begonia species exhibited high activity against $C$. freundii. The most effective plants among species screened against Citrobacter freundii locally isolated were B. thiemei, B. foliosa, and Begonia $\times$ erythrophylla being highly active with the ethanolic extract (diameters of inhibition zone were ranged from 16.5 to $26 \mathrm{~mm}$ ). The highly active antimicrobial effects of extracts obtained from B. thiemei, B. foliosa noted against Citrobacter freundii are worthy of highlighting. The identification of active compounds and their mode of action requires further investigation for antibacterial drug development.
\end{abstract}

Keywords: Begonia, leaf ethanolic extracts, antibacterial activity, inhibition zones, disc diffusion technique

\footnotetext{
*Corresponding author: Halyna Tkachenko, Institute of Biology and Earth Sciences, Pomeranian University in Słupsk, Arciszewski 22b, 76-200 Słupsk, Poland $\triangle$ tkachenko@apsl.edu.pl
} 


\section{Introduction}

Begonia L. is one of the most species-rich angiosperm genera with approximately 1,500 species currently recognized (Frodin, 2004). Representatives of Begonia genus are widely known as popular ornamental plants but the medicinal importance of its members is sparsely known. A few papers have been published, providing information regarding the medical properties of various Begonia species (Indrakumar et al., 2014; Amutha and Sreedevikumari, 2016; Shrestha et al., 2016). For instance, its leaves, flowers, and roots are used in diverse ailments in traditional and folklore remedies. Moreover, the leaves of Begonia species are used for the treatment of cancer and possess anti-HIV activity (Wu et al., 2004).

Plants belonging to the Begonia genus can be good candidates for as an alternative therapy in restricting the resistant infectious organisms. Some of the plants of the genus Begonia were previously reported for their antimicrobial activities (Holetz et al., 2002; Indrakumar et al., 2014; Amutha and Sreedevikumari, 2016; Shrestha et al., 2016). The antimicrobial activities of volatile compounds of intact plants of 24 Begonia species have been assessed against several pathogenic microorganisms (i.e. Staphylococcus epidermidis, Escherichia coli, and Candida albicans). As a result, 14 Begonia species, possessing well expressed phytoncide activity have been recommended to use as indoor plants, based on their ability to reduce microbial air pollution indoor by a factor of 1,5-3,0 in particular, by decreasing the Staphylococcus aureus load (Karpova et al., 2009, Tsybulia et al., 2011).

The genus Citrobacter belongs to the family of Enterobacteriaceae and comprises 11 different species of facultatively anaerobic, motile, Gram-negative bacilli, which are oxidase-negative and typically utilize citrate as the sole carbon source (Hodges et al., 1978; Janda et al., 1994; Samonis et al., 2009). Among Citrobacter species, the most commonly isolated from human clinical specimens are C. koseri (formerly named C. diversus), C. freundii, C. youngae, C. braakii, and $C$. amalonaticus, while the majority of cases of infection are associated with $C$. koseri and C. freundii (Janda et al., 1994; Samonis et al., 2009). Citrobacter freundii is recognized as an emerging opportunistic pathogen and is known to cause a variety of ailments (e.g., urinary tract infections, wound infections, gastrointestinal infections, septicemia, meningitis), especially in immunocompromised patients and in-hospital settings (Brenner et al., 1993; Gupta et al., 2003; Samonis et al., 2009; Ranjan and Ranjan, 2013; Leski et al., 2016). This emergence has coincided with the finding that $C$. freundii is often resistant to multiple antibiotics, suggesting that both clinical and environmental strains may be important reservoirs of antimicrobial resistance determinants (ARDs) (Pepperell et al., 2002; Leski et al., 2016). Citrobacter infections were found to represent $0.8 \%$ of Gram-negative infections in a large surveillance study (Jones et al., 2000; Samonis et al., 2009). Moreover, in hospital settings, Citrobacter spp. have accounted for 3-6\% of all isolates of Enterobacteriaceae (Lipsky et al., 1980; Samonis et al., 2009; Lavigne et al., 20117). The mortality rate of hospitalized patients with Citrobacter infections has been observed to be 6.8\% (Mohanty et al., 2007).

Considering the points highlighted above and based on previous results obtained in our laboratory, the aim of the present study was to find out in vitro possible antimicrobial action of the ethanolic extracts from leaves of nine Begonia species against Citrobacter freundii strain locally isolated. 


\section{Materials and methodology}

\section{Collection of Plant Materials. Collection of Plant Material}

The leaves of Begonia plants, cultivated under glasshouse conditions, were sampled at M.M. Gryshko National Botanic Garden (NBG), National Academy of Science of Ukraine. The leaves of Begonia solimutata L.B. Sm. \& Wassh., Begonia goegoensis N.E.Br., Begonia foliosa Kunth, Begonia $\times$ erythrophylla Hérincq, Begonia thiemei C.DC. (syn. Begonia macdougallii Ziesenh.), Begonia peltata Otto \& Dietr. (syn. Begonia kellermanii C.DC.), Begonia heracleifolia Cham. \& Schltdl., Begonia dregei Otto \& Dietr., Begonia mexicana G. Karst. ex Fotsch was sampled for our study. The antimicrobial screening of Begonia leaf extracts has been carried out.

\section{Preparation of Plant Extracts}

The leaves were brought into the laboratory for antimicrobial studies. Freshly crushed leaves were washed, weighed, and homogenized in $96 \%$ ethanol (in proportion $1: 19, \mathrm{w} / \mathrm{w}$ ) at room temperature. The extracts were then filtered and investigated for their antimicrobial activity.

\section{Bacterial test strain and growth conditions}

The non-repetitive clinical strain of Citrobacter freundii isolated from patients with uretic infection was collected from Koszalin Hospital during March-April, 2019. The purity, as well as the identity of isolate, was confirmed in the laboratory conditions by standard microbiological methods and were interpreted according to the guidelines of the Clinical Laboratory Standards Institute (2014).

Susceptibility testing of the isolate was performed by disk diffusion according to the Guidelines of Clinical and Laboratory Standard Institute (CLSI, 2014). The antibiotics tested were piperacillin, piperacillin-tazobactam, cefepime, cefotaxime, ceftazidime, cefuroxime, aztreonam, imipenem, meropenem, ertapenem, amikacin, gentamicin, trimethoprim-sulphamethoxazole, ciprofloxacin, levofloxacin, tetracycline, tigecycline, and polymyxin B. Results were interpreted according to CLSI criteria. MIC was determined by $E$-test strips (according to manufacturer's instruction) and agar dilution method (according to the Guidelines of Clinical and Laboratory Standard Institute). The resistance breakpoints were the same as the ones defined by the National Committee for Clinical Laboratory Standards (NCCLS, 2014).

The cultivation medium was trypticase soy agar (Oxoid, UK), supplemented with $10 \%$ defibrinated sheep blood. Cultures were grown aerobically for $24 \mathrm{~h}$ at $37{ }^{\circ} \mathrm{C}$. The cultures were later diluted with a sterile solution of $0.9 \%$ normal saline to approximate the density of 0.5 McFarland standard. The McFarland standard was prepared by inoculating colonies of the bacterial test strain in sterile saline and adjusting the cell density to the specified concentration. Citrobacter freundii strain studied was susceptible to all antibiotics used.

\section{Determination of the antibacterial activity of plant extracts by the disk diffusion method}

The testing of the antibacterial activity of the plant extracts was carried out in vitro by the Kirby-Bauer disc diffusion technique (Bauer et al., 1966). The strain was inoculated onto Mueller-Hinton (MH) agar plates. Sterile filter paper discs impregnated with extracts were 
applied over each of the culture plates. Isolates of bacteria were then incubated at $37{ }^{\circ} \mathrm{C}$ for $24 \mathrm{~h}$. The plates were then observed for the zone of inhibition produced by the antibacterial activity of ethanolic extract obtained from the leaves of various extracts of plants belonging to the Begonia genus. A negative control disc impregnated with sterile ethanol was used in each experiment. At the end of the period, the inhibition zones formed were measured in millimeters using the vernier. For each extract, eight replicates were assayed. The plates were observed and photographs were taken. The susceptibility of the test organisms to the plant extracts was indicated by a clear zone of inhibition around the holes containing the plant extracts and the diameter of the clear zone was taken as an indicator of susceptibility. Zone diameters were determined and averaged.

\section{Statistical analysis}

Zone diameters were determined and averaged. Statistical analysis of the data obtained was performed by employing the mean \pm standard error of the mean (S.E.M.). All variables were randomized according to the phytochemical activity of extracts tested. All statistical calculation was performed on separate data from each strain. The data were analyzed using a one-way analysis of variance (ANOVA) using Statistica v. 8.0 software (StatSoft, Poland) (Zar, 1999). The following zone diameter criteria were used to assign susceptibility or resistance of bacteria to the phytochemicals tested: Susceptible $(S) \geq 15 \mathrm{~mm}$, Intermediate $(I)=10-15 \mathrm{~mm}$, and Resistant $(R) \leq 10 \mathrm{~mm}$ (Okoth et al., 2013).

\section{Results and discussion}

Antimicrobial activities of various ethanolic extracts obtained from leaves of various plants belonged to the Begonia genus against $C$. freundii measured as an inhibition zone diameter are presented in Figure 1 and 2. The present study has shown that all ethanolic extracts obtained from leaves of Begonia species exhibited high activity against $C$. freundii. The diameter of the inhibition zone for B. solimutata was $(15.5 \pm 1.1) \mathrm{mm}$, for B. goegoensis $-(18.1 \pm 1.2) \mathrm{mm}$, for B. foliosa - (21.5 \pm 1.5$) \mathrm{mm}$, for Begonia $\times$ erythrophylla $-(18.8 \pm 1.2) \mathrm{mm}$, for $B$. thiemei $(22.5 \pm 1.5) \mathrm{mm}$, for $B$. peltata $-(16.8 \pm 1.3) \mathrm{mm}$, for $B$. heracleifolia $-(13.2 \pm 1.1) \mathrm{mm}$, for B. dregei - (11.8 \pm 0.8$) \mathrm{mm}$, and for B. mexicana - $(12.5 \pm 0.6) \mathrm{mm}$ (Figure 1 and 2$)$.

Detailed data regarding the zones of inhibition by the various plant extracts were recorded and presented in Figure 2.

It should be noted that the most effective plants among species screened against Citrobacter freundii locally isolated were B. thiemei, B. foliosa, and Begonia $\times$ erythrophylla, being highly active with the ethanolic extract (diameters of inhibition zone were ranged from 16.5 to $26 \mathrm{~mm}$ ). The highly active antimicrobial effects of extracts obtained from B. thiemei, B. foliosa noted against Citrobacter freundii are worthy of highlighting.

In our previous study (Tkachenko et al., 2016), we have also demonstrated that the ethanolic extracts obtained from leaves of Begonia species had moderate activity against Escherichia coli. The diameters of inhibition zone for B. solimutata were $14 \mathrm{~mm}, 11.5 \mathrm{~mm}$ for B. goegoensis, $13 \mathrm{~mm}$ for B. foliosa, $13.5 \mathrm{~mm}$ for Begonia $\times$ bunchii, $15 \mathrm{~mm}$ for B. thiemei, 
$19 \mathrm{~mm}$ for B. peltata, $12 \mathrm{~mm}$ for B. heracleifolia, $11.5 \mathrm{~mm}$ for $B$. dregei, and $16 \mathrm{~mm}$ for B. mexicana. The highest antimicrobial effect was recorded for B. peltata, B. mexicana, and B. thiemei. The most antimicrobial effective plant against E. coli was B. peltata, being highly active with the ethanolic extract (diameter of inhibition zone was $19 \mathrm{~mm}$ ). The highly active antimicrobial effects noted against E. coli are worthy of highlighting (Tkachenko et al., 2016). Moreover, the ethanolic extract from the leaves of B. goegoensis exhibited strong activity against Pseudomonas aeruginosa (inhibition zone diameter ranged from $12 \mathrm{~mm}$ to $13 \mathrm{~mm}$ ), while methanolic leaf extract screened revealed less profound activity (within 11-12.5 mm) in our previous study (Tkachenko et al., 2017). Moreover, it has been observed that ethyl acetate, hexane and dichloromethane extracts obtained from leaves of B. goegoensis revealed no antibacterial activity against $P$. aeruginosa and $\beta$-lactamases producing $P$. aeruginosa (MBL-positive $P$. aeruginosa) strains. MBL-positive $P$. aeruginosa was also susceptible to ethanolic and methanolic extracts (inhibition zone diameter ranged from $12.5 \mathrm{~mm}$ to $15.5 \mathrm{~mm}$ ) (Tkachenko et al., 2017).

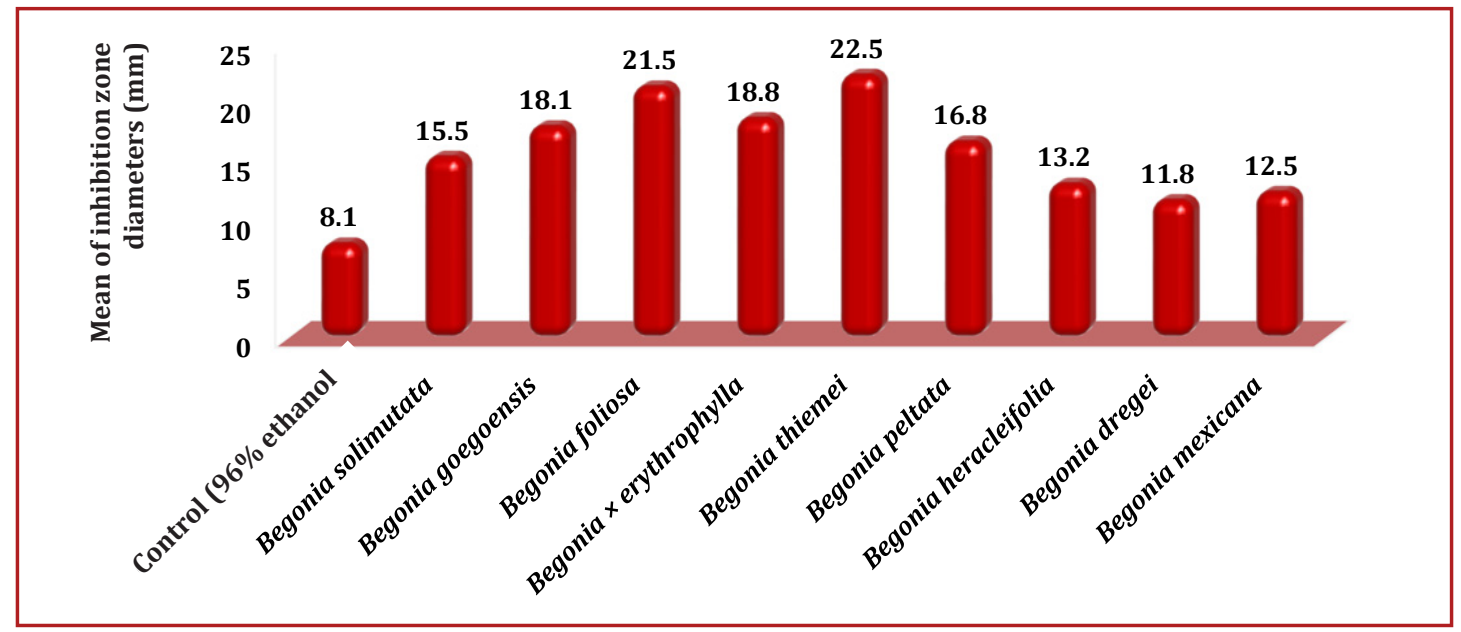

Figure 1 Antimicrobial activity of various extracts obtained from leaves of various plants belonged to the Begonia genus against Citrobacter freundii measured as inhibition zone diameter

Similar antimicrobial effect of various plants belonged to Begonia genus was also demonstrated by other researchers. For example, Siregar et al. (2018) have demonstrated the antibacterial potency of simple fractions of ethyl acetate extract of Begonia baliensis Girm. from Bukit Sangyang, Penebel, Tabanan-Bali. The chemical compounds of ethyl acetate extracts were isolated and separated by column chromatography. The obtained fractions were analyzed for antibacterial activity by disc diffusion assay against Escherichia coli, Bacillus subtilis, Staphylococcus epidermidis and Staphylococcus aureus. The chromatographic column yielded 14 simple fractions, whereas antibacterial test results showed 5 active fractions. Fraction 3 was active against S. epidermidis, fraction 5 against $E$. coli and S. epidermidis, while fractions 10, 11 and 12 were active only against Bacillus subtilis (Siregar et al., 2018). 
Buyun, L., Tkachenko, H., Kurhaluk, N., Góralczyk, A., Tomin, V., Osadowski, Z.

Agr.bio.div. Impr. Nut., Health Life Qual., 2019, 312-322
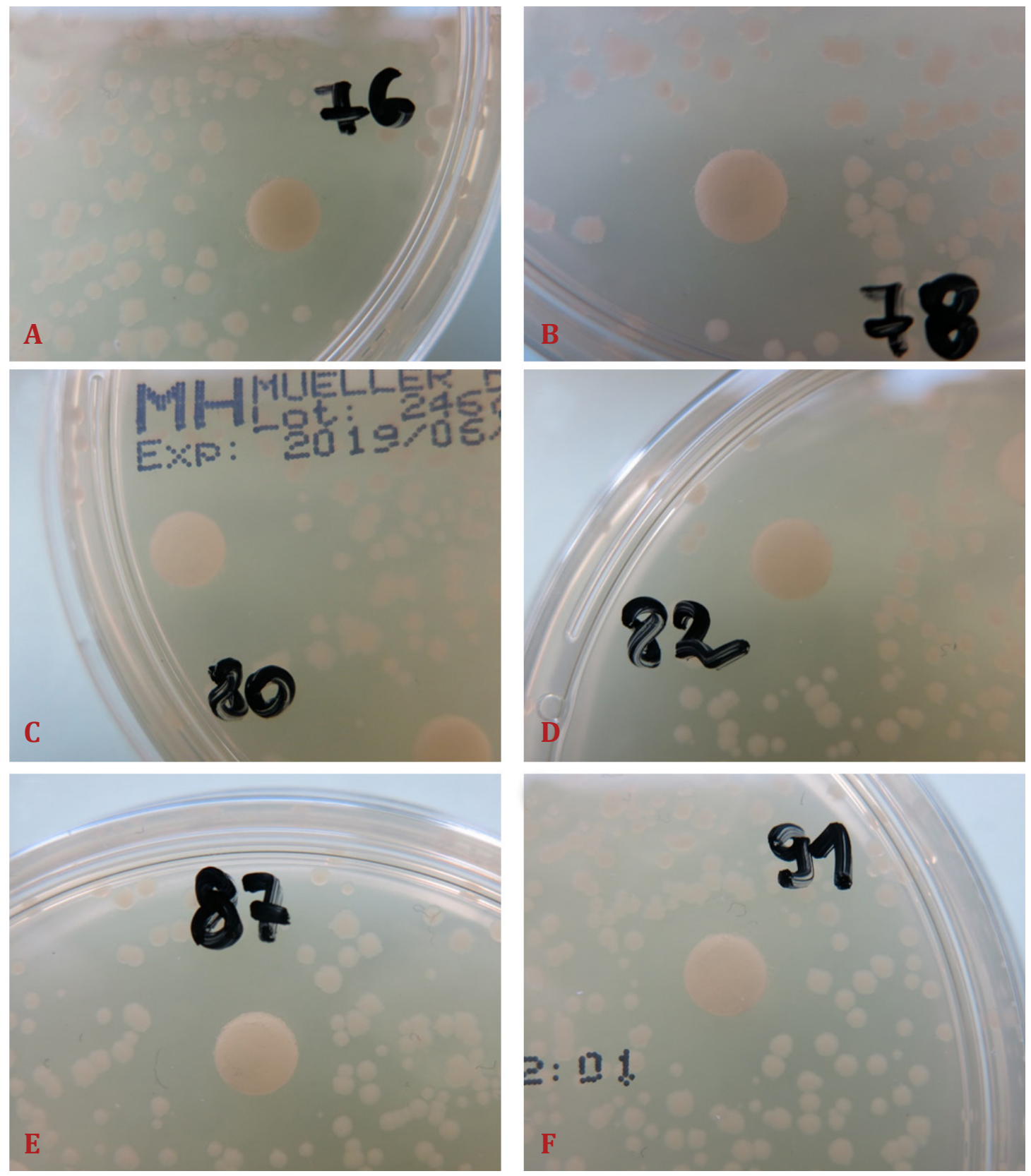

Figure 2 Inhibition zones induced by various ethanolic extracts obtained from leaves of Begonia goegoensis (A), B. foliosa (B), Begonia $\times$ erythrophylla (C), B. thiemei (D), B. peltata (E), and $B$. heracleifolia $(\mathrm{F})$ against Citrobacter freundii growth

Antimicrobial properties of Begonia fischeri var. palustris plantlets were assessed by Karpova et al. (2019). Flavonoid composition of the leaves of in vitro plantlets and greenhouse stock plants had no substantial differences. Significant differences between flavonoid contents of the leaves [13.6 and $15.5 \mathrm{mg} / \mathrm{g}$ of dry weight (DW), respectively], were not found. 
Aqueous ethanolic extracts of plants showed antimicrobial effects against reference strains of Bacillus subtilis, Streptococcus pyogenes and Staphylococcus aureus. The concentration of flavonoids in acetone and ethanol extracts of exudative compounds of the leaves of in vitro plantlets was 0.02 and $2.0 \mathrm{mg} / \mathrm{g}$ DW, respectively (Karpova et al., 2019).

Jeeva and Antonisamy (2012) have investigated the antibacterial activity and phytochemical properties of Begonia floccifera Bedd. methanolic flower extracts against the selected pathogens (Escherichia coli, Klebsiella pneumonia, Pseudomonas aeruginosa, Staphylococcus aureus, Bacillus cereus, Salmonella typhi, Serratia marcescens, Proteus mirabilis, Enterococcus faecalis, and Streptococcus pyogenes) by the disc diffusion method. The results of the phytochemical screening revealed that phenol, tannins, xanthoproteins, steroids, phytosterols, triterpenoids, sapogenins, coumarins, and carbohydrates are comprised in the methanolic extracts of B. floccifera. The antibacterial activity has been observed in the methanolic extracts of $B$. floccifera against the tested bacteria with varied activity. The maximum diameter of inhibition zone was $28 \mathrm{~mm}$ for B. cereus, $25 \mathrm{~mm}$ for $S$. aureus, $15 \mathrm{~mm}$ for E. coli, $13 \mathrm{~mm}$ for P. mirabilis, $7 \mathrm{~mm}$ for K. pneumonia. The other pathogens viz., P. aeruginosa, S. typhi, S. marcescens, Enterobacter spp., E. faecalis, and S. pyogenes showed the minimal susceptibility to inhibition by extracts tested. Thus, methanolic flower extracts of B. floccifera can be used to treat nausea, vomiting, diarrhea, urinary tract infections, nosocomial infections, pneumonia, septicemias, etc. (Jeeva and Antonisamy, 2012).

Phytochemical investigation of the various extracts of the leaves of Begonia malabarica Lam. resulted in the isolation and identification of six known compounds, viz. friedelin, epi-friedelinol, $\beta$-sitosterol, luteolin, quercetin, and $\beta$-sitosterol-3- $\beta$-d-glucopyranoside in the study of Ramesh et al. (2002). The aqueous and organic solvent extracts were also tested against ten human pathogenic bacteria and four fungal strains by the agar well diffusion method. All the extracts were devoid of antifungal activity against the tested fungi. The hexane extract did not show any activity. The aqueous extracts showed activity against the Gram-negative bacteria except for Vibrio parahaemolyticus. The chloroform and methanol extracts showed activity against all the tested bacteria (Ramesh et al., 2002). Shobi et al. (2018) have studied the antibacterial activity of di-butyl phthalate isolated from B. malabarica. It was extracted with various solvents and bioactive compounds were isolated using chromatographic techniques. One of the bioactive compounds isolated from it was a colorless or pale yellow oily compound that is soluble in chloroform. The structure of the compound was elucidated as di-butyl phthalate with the help of spectral data. The compound is reported to have antibacterial and anticancer properties. Dibutyl phthalate showed a $9 \mathrm{~mm}$ zone of inhibition against Staphylococcus epidermidis, Strephtococcus pneumoniae, Escherichia coli, Micrococcus luteus, Klebsiella pneumoniae, Shigella flexneri, Vibrio cholerae and $P$. aeruginosa at the concentration of $100 \mathrm{mg} / \mathrm{ml}$. Similar zone of inhibition recorded at all the concentrations of E. coli and Pseudomonas aeruginosa. Eight mm zone of inhibition was recorded against Strephtococcus pneumoniae at 50, 25 and $12.5 \mathrm{mg} / \mathrm{ml}$. Staphylococcus epidermidis, Klebsiella pneumoniae, and Shigella flexneri also showed an $8 \mathrm{~mm}$ zone of inhibition at 25, 12.5 and $6.25 \mathrm{mg} / \mathrm{ml}$ concentrations (Shobi et al., 2018). 
Other researchers also demonstrated the necessitates of using medicinal plants as an alternative therapy in restricting the resistant infectious organisms. In the study of Narayanan et al. (2011), the antibiotic resistances of organisms isolated from urinary tract infected patients were evaluated using the National Committee for Clinical Laboratory Standards (NCCLS) method and Multiple Antibiotic Resistance (MAR) index values, and the MAR values were also calculated for plant extracts. The 10 common medicinal plants collected from Kolli Hills, Namakkal, South India were extracted using the chloroform, methanol, acetone, ethanol and saponification procedure. The efficacy of the extracts on the uropathogens was tested by agar disc diffusion method in order to analyze the inhibitory activity of plant extract on the organisms. Azadiracta indica A. Juss., Tinospora cordifolia (Wild.) and Euphorbia hirta Linn. exhibited high inhibitory activity against most of the 11 tested organisms followed by Cassia javanica Linn. and Phyllanthus niruri Linn. The maximum zone size of $46.3 \mathrm{~mm}$ was exhibited by methanol extract of $P$. niruri Linn. against Pseudomonas aeruginosa. Asparagus racemosus Willd. and Eupatorium triplinerve Vahl had the least activity against resistant pathogens. Saponified lipids of most of the plants exhibited maximum antibacterial activity. Among the tested organisms, P. aeruginosa and Staphylococcus epidermidis were the most susceptible and Serratia marcescens, Enterobacter cloacae, Citrobacter koseri, and Citrobacter freundii were the least inhibited by most of the extracts of medicinal plants (Narayanan et al., 2011).

Variation in the chemical profile of extracts could influence their biological activities. Therefore, it was important to evaluate the chemical composition of extracts to correlate with their antimicrobial activities. A study conducted by Kalpanadevi and Mohan (2012) has shown that the extracts of $B$. malabarica and $B$. floccifera leaves contain higher quantities of phenolic compounds, which exhibit antioxidant and free radical scavenging activity. In vitro assay systems confirmed B. malabarica and B. floccifera whole plants as natural antioxidants. The phenolics and flavonoids could be the reason for its antioxidant activity. The preliminary phytochemical studies revealed the presence of flavone, sterol, triterpene in hexane, chloroform, and methanol extracts; phenol in chloroform and methanol extracts of B. malabarica and quinone, saponin, tannin, and starch in methanol extract. All the extracts did not answer for alkaloids (Ramesh et al. 2002). Preliminary phytochemical screening of B. floccifera and B. malabarica conducted by Ariharan et al. (2012) showed the presence of vitamin $C$ in the leaves of both plant species assayed. Apparently, the antimicrobial activity of the leaf extracts of these Begonia species screened against pathogenic strains of Gram-positive (Staphylococcus aureus, S. epidermidis) and Gramnegative (Pseudomonas aeurogenosa, Salmonella typhimurium) bacteria could be due to the presence of this phytoconstituent. Additionally, the flavonoids content (including glycosides of quercetin and kaempferol), anthocyanins and ascorbic acid in overground part of plants of 7 species and cultivars of genus Begonia L. (B. bahiensis, B. bowerae, B. carolineifolia, B. fischeri, B. heracleifolia, B. 'Erythrophylla', B. 'Helen Teupel') were determined by Karpova et al. (2009). The flavonoids content was $24-650 \mathrm{mg} \%$ of dry weight, including glycosides of quercetin - 3-76 mg\%. Kaempferol glycosides were detected only in species of section Gireoudia (1.2-5.7 mg\%). The contents of anthocyanins were between 60 and $157 \mathrm{mg} \%$, ascorbic acid - 5-43 mg\% of fresh weight. These results suggest that studied plants of Begonia 
species can be considered as the sources of biologically active compounds with antioxidant and antimicrobial activities (Karpova et al., 2009).

\section{Conclusions}

This in vitro study corroborated the antimicrobial activity of the selected plants belonged to Begonia genus. All these plants were effective against Citrobacter freundii strain locally isolated. This study also showed that B. thiemei, B. foliosa, and Begonia $\times$ erythrophylla could be potential sources of new antimicrobial agents. The identification of active compounds and their mode of action requires further investigation for antibacterial drug development.

\section{References}

AMUTHA, S., SREEDEVIKUMARI, T. 2016. Evaluation of antibacterial activity of different solvent extracts of Begonia cordifolia. In Int. J. Zool. Appl. Biosci., vol. 1(3), p. 144-147.

ARIHARAN, V.N., MEENA DEVI, V.N., RAJAKOKHILA, M., NAGENDRA PRASAD, P. 2012. A new natural source for vitamin C. In International Journal of Plant, Animal and Environmental Sciences, vol. 2(3), p. 92-94.

BAUER, A.W., KIRBY, W.M., SHERRIS, J.C., TURCK, M. 1966. Antibiotic susceptibility testing by a standardized single disk method. In Am. J. Clin. Pathol., vol. 45(4), p. 493-496.

BRENNER, D.J., GRIMONT, P.A., STEIGERWALT, A.G., FANNING, G.R., AGERON, E., RIDDLE, C.F. 1993. Classification of citrobacteria by DNA hybridization: designation of Citrobacter farmeri sp. nov., Citrobacter youngae sp. nov., Citrobacter braakii sp. nov., Citrobacter werkmanii sp. nov., Citrobacter sedlakii sp. nov., and three unnamed Citrobacter genomospecies. In Int. J. Syst. Bacteriol., vol. 43(4), p. 645-658. http://dx.doi.org/10.1099/00207713-43-4-645

CLSI. Performance Standards for Antimicrobial Susceptibility Testing. Clinical and Laboratory Standards Institute; Wayne, PA, USA: 2014. CLSI M100-S24.

FRODIN, D.G. 2004. History and concepts of big plant genera. In Taxon, vol. 53, p. 753-776. https://doi. org/10.2307/4135449

GUPTA, N., YADAV, A., CHOUDHARY, U., ARORA, D.R. 2003. Citrobacter bacteremia in a tertiary care hospital. In Scand.J. Infect. Dis., vol. 35, p. 765-768. https://doi.org/10.1080/00365540310016376

HODGES, G.R., DEGENER, C.E., BARNES, W.G. 1978. Clinical significance of Citrobacter isolates. In Am. J. Clin. Pathol., vol. 70(1), p. 37-40. https://doi.org/10.1093/ajcp/70.1.37

HOLETZ, F.B., PESSINI, G.L., SANCHES, N.R., CORTEZ, D.A., NAKAMURA, C.V., FILHO, B.P. 2002. Screening of some plants used in Brazilian folk medicine for the treatment of infectious diseases. In Mem. Inst. Oswaldo Cruz, vol. 97, p. 1027-1031.

INDRKUMAR, I., GOMATHI, R., KARPAGAM, S. 2014. Antimicrobial and In vitro Antioxidant Potential of Begonia dipetala Graham. In Int. J. Pharm. Sci. Rev. Res., vol. 27(2), p. 382-386.

JANDA, J.M., ABBOTT, S.L., CHEUNG, W.K., HANSON, D.F. 1994. Biochemical identification of citrobacteria in the clinical laboratory. In J. Clin. Microbiol., vol. 32(8), p. 1850-1854.

JEEVA, S., ANTONISAMY, J.M. 2012. Anti-bacterial and phytochemical studies on methanolic extracts of Begonia floccifera Bedd. flower. In Asian Pacific Journal of Tropical Biomedicine, vol. 2(1 Suppl.), p. S151-S154. https://doi.org/10.1016/S2221-1691(12)60147-6

JONES, R.N., JENKINS, S.G., HOBAN, D.J., PFALLER, M.A., RAMPHAL, R. 2000. In vitro efficacy of six cephalosporins tested against Enterobacteriaceae isolated at 38 North American medical centres participating in the SENTRY Antimicrobial Surveillance Program, 1997-1998. In Int. J. Antimicrob. Agents, vol. 15(2), p. 111-118. https://doi.org/10.1016/S0924-8579(00)00152-7 
KALPANADEVI, V., MOHAN, V.R. 2012. In vitro antioxidant studies of Begonia malabarica Lam. and Begonia floccifera Bedd. In Asian Pacific Journal of Tropical Biomedicine, vol. 2(3), p. S1572-S1577. https://doi.org/10.1016/S2221-1691(12)60455-9

KARPOVA, E., NABIEVA, A., FERSHALOVA, T., YAKIMOVA, Y., TSYBULYA, N. 2019. Flavonoids and Antimicrobial Properties of Begonia fischeri var. palustris in vitro Plantlets. In OnLine Journal of Biological Sciences, vol. 19(1), p. 20-27. https://doi.org/10.3844/ojbsci.2019.20.27

KARPOVA, E.A., KCHRAMOVA, E.P., FERSHALOVA, T.D. 2009. Flavonoids and ascorbic acid in the representatives of the genus Begonia L. In Khimiya rastitel'nogo syrya (Chemistry of plant raw material), vol. 2, p. 105-110.

LAVIGNE, J.P., DEFEZ, C., BOUZIGES, N. MAHAMAT, A., SOTTO, A. 2007. Clinical and molecular epidemiology of multidrug-resistant Citrobacter spp. infections in a French university hospital. In Eur. J. Clin. Microbiol. Infect. Dis., vol. 26, p. 439--441. https://doi.org/10.1007/s10096-007-0315-3

LESKI, T.A., TAITT, C.R., BANGURA, U., ANSUMANA, R., STENGER, D.A., WANG, Z., VORA, G.J. 2016. Finished Genome Sequence of the Highly Multidrug-Resistant Human Urine Isolate Citrobacter freundii Strain SL151. In Genome Announc., vol. 4(6). pii: e01225-16. https://doi.org/10.1128/ genomeA.01225-16

LIPSKY, B.A., HOOK, E.W. 3RD, SMITH, A.A., PLORDE, J.J. 1980. Citrobacter infections in humans: experience at the Seattle Veterans Administration Medical Center and a review of the literature. In Rev. Infect. Dis., vol. 2(5), p. 746-760. https://doi.org/10.1093/clinids/2.5.746

MOHANTY, S., SINGHAL, R., SOOD, S., DHAWAN, B., KAPIL, A., DAS, B.K. 2007. Citrobacter infections in a tertiary care hospital in Northern India. In J. Infect., vol. 54, p. 58-64. https://doi.org/10.1016/j. jinf.2006.01.015

NARAYANAN, A.S., RAJA, S.S., PONMURUGAN, K., KANDEKAR, S.C., NATARAJASEENIVASAN, K., MARIPANDI, A., MANDEEL, Q.A. 2011. Antibacterial activity of selected medicinal plants against multiple antibiotic resistant uropathogens: a study from Kolli Hills, Tamil Nadu, India. In Benef. Microbes, vol. 2(3), p. 235-243. https://doi.org/10.3920/BM2010.0033

OKOTH, D.A., CHENIA, H.Y., KOORBANALLY, N.A. 2013. Antibacterial and antioxidant activities of flavonoids from Lannea alata (Engl.) Engl. (Anacardiaceae). In Phytochem. Lett., vol. 6, p. 476-481. https://doi.org/10.1016/j.phytol.2013.06.003

PEPPERELL, C., KUS, J.V., GARDAM, M.A., HUMAR, A., BURROWS, L.L. 2002. Low-virulence Citrobacter species encode resistance to multiple antimicrobials. In Antimicrob. Agents Chemother., vol. 46, p. 3555-3560. https://doi.org/10.1128/AAC.46.11.3555-3560.2002

RAMESH, N., VISWANATHAN, M.B., SARASWATHY, A., BALAKRISHNA, K., BRINDHA, P., LAKSHMANAPERUMALSAMY, P. 2002. Phytochemical and antimicrobial studies of Begonia malabarica. In J. Ethnopharmacol., vol. 79(1), p. 129-132. https://doi.org/10.1016/ S0378-8741(01)00352-X

RANJAN, K.P., RANJAN, N. 2013. Citrobacter: an emerging healthcare-associated urinary pathogen. In Urol. Ann., vol. 5, p. 313-314. http://www.urologyannals.com/text.asp?2013/5/4/313/120297

SAMONIS, G., KARAGEORGOPOULOS, D.E., KOFTERIDIS, D.P., MATTHAIOU, D.K., SIDIROPOULOU, V., MARAKI, S., FALAGAS, M.E. 2009. Citrobacter infections in a general hospital: characteristics and outcomes. In Eur. J. Clin. Microbiol. Infect. Dis., vol. 28(1), p. 61-68. https://doi.org/10.1007/ $\underline{\text { s10096-008-0598-Z }}$

SHOBI, T.M., VISWANATHAN, M.B.G. 2018. Antibacterial activity of di-butyl phthalate isolated from Begonia malabarica. In J. Appl. Biotechnol. Bioeng., vol. 5(2), p. 101-104. https://doi.org/10.15406/ jabb.2018.05.00123

SHRESTHA, N., ITANI, R., KHANAL, D.P. 2016. Pharmacognostic, phytochemical, antioxidant and antibacterial activity studies on Begonia picta. In World Journal of Pharmaceutical Research, vol. 5(1), p. 979-997. 
SIREGAR, H.M., PURWANTORO, R.S., PRAPTIWI AGUSTA, A. 2018. Antibacterial potency of simple fractions of ethyl acetate extract of Begonia baliensis. In Nusantara Bioscience, vol. 10, p. 159-163. https://doi.org/10.13057/nusbiosci/n100305

TKACHENKO, H., BUYUN, L., OSADOWSKI, Z. 2017. The antimicrobial properties of extracts obtained from Begonia goegoensis N.E.Br. leaf against Pseudomonas aeruginosa isolates. In Agrobiodiversity for improving nutrition, health, and life quality, (1), p. 454-460. http://dx.doi.org/10.15414/ agrobiodiversity.2017.2585-8246.454-460

TKACHENKO, H., BUYUN, L., OSADOWSKI, Z., BELAYEVA, Y. 2016. In vitro microbiological investigation of ethanolic extracts obtained from leaves of various Begonia species against Escherichia coli. In Słupskie Prace Biologiczne, vol. 13, p. 277-294.

TSYBULYA, N.V., FERSHALOVA, T.D., YAKIMOVA, YU.L. 2010. Examination of the antimicrobial activity of some g. Begonia L. species as a possible piece of phytodesign. In Aerokosmicheskaya i ekologicheskaya meditsina (Aerospace and Environmental Medicine), vol. 44(1), p. 47-50 (In Russian).

WU, P.L., LIN, F.W., WU, T.S., KUOH, C.S., LEE, K.H., LEE, S.J. 2004. Cytotoxic and anti-HIV principles from the rhizomes of Begonia nantoensis. In Chem. Pharm. Bull. (Tokyo), vol. 52(3), p. 345-349. https:// doi.org/10.1248/cpb.52.345

ZAR, J.H. 1999. Biostatistical Analysis. $4^{\text {th }}$ ed., Prentice-Hall Inc., Englewood Cliffs, New Jersey. 